\title{
Efficacy of conventional drinking water treatment processes in removing problem-causing phytoplankton and associated organic compounds
}

\author{
H Ewerts $^{1,2 *}$, A Swanepoel ${ }^{2}$ and HH du Preez ${ }^{2,3}$ \\ 'School of Environmental Sciences and Development, North-West University (Potchefstroom Campus), \\ Private Bag X6001, Potchefstroom, 2520, South Africa \\ ${ }^{2}$ Rand Water Analytical Services, PO Box 3526, Vereeniging, 1930, South Africa \\ ${ }^{3}$ Department of Zoology, University of Johannesburg, Auckland Park, South Africa
}

\begin{abstract}
Seven phytoplankton groups were recorded in the source water supplied to South Africa's largest conventional drinking water treatment plant (DWTP). Two phytoplankton genera, Anabaena and Ceratium were identified as the problem-causing phytoplankton due to their ability to interfere with the water treatment process and negatively impact on water quality. The objectives of this study were to identify problem-causing phytoplankton genera and investigate the efficacy of unit processes in removing phytoplankton genera and associated organic compounds. Phytoplankton and organic compound data were obtained from four different sampling localities throughout the treatment plant and statistically analysed to evaluate the removal efficiencies of unit processes. The highest percentage removal for the Cyanophyceae average seasonal concentration (> 1000 cells $/ \mathrm{m} \ell$ ) was recorded at $98 \%$, while the highest percentage removal for the Dinophyceae average seasonal concentration $( \pm 9$ cells $/ \mathrm{ml})$ was recorded at $100 \%$. Microcystis and Anabaena were removed by the processes of coagulation, flocculation and sedimentation $(>95 \%$ ), while Ceratium cells were removed by sand filtration ( $>80 \%)$. Ineffective removal of Ceratium by coagulation, flocculation and sedimentation (and subsequent penetration to the sand filtration step) will negatively impact on filter run times when these phytoplankton genera are present in high concentrations in the source water. Total photosynthetic pigments (TPP) were removed effectively by all the different water treatment processes. Not enough statistical evidence could be displayed to suggest effective removal of geosmin in this conventional water treatment plant. With good removal of intact cyanobacteria cells during coagulation, flocculation and sedimentation, geosmin concentrations in the final water could be kept to accepted organoleptic levels of $5-10 \mathrm{ng} / \ell$ in the final water. Optimising conventional drinking water treatment processes can effectively remove problem-causing phytoplankton as well as their associated organic compounds and thereby reduce the potential risk to drinking water consumers.
\end{abstract}

Keywords: coagulation, sand filtration, drinking water, Ceratium, Anabaena, Microcystis, geosmin

\section{INTRODUCTION}

Pollution and eutrophication lead to the presence of high concentrations of organic and inorganic compounds, which enhance phytoplankton (including Cyanophyceae) blooms and concomitantly decrease water quality (Venter et al., 2003; Heisler et al., 2008 and Li et al., 2011). The occurrence of these blooms in the source water for drinking water production is of critical importance to drinking water providers as phytoplankton can have both a physical impact (e.g. clogging of filters) and chemical impact (e.g. production of cyanotoxins, disinfection by-products and taste and odour compounds) on the treatment process (Du Preez et al., 2007; Merel et al., 2010).

Phytoplankton known to cause problems during drinking water treatment, include groups like Dinophyceae (Ceratium hirundinella), Cyanophyceae (Microcystis aeruginosa, Anabaena circinalis, Oscillatoria simplicissma and Cylindrospermopsis), Bacillariophyceae (Aulacoseira granulata) as well as the Chlorophcyeae (Cladophora). Ceratium,

To whom all correspondence should be addressed.

iㅏ. +27 16430 8827; fax: +27 16455 2055;

e-mail: hewerts@randwater.co.za

Received 7 August 2012; accepted in revised form 7 October 2013. for example, is known to disrupt the coagulation, flocculation and sedimentation processes and clog sand filters as well as to produce taste and odour compounds (Swanepoel et al., 2008a). Cyanophyceae blooms add an additional dimension as the toxic strains of the different species can produce cyanotoxins that pose a health risk to the consumers of drinking water $(\mathrm{Du}$ Preez et al., 2007 and Newcombe, 2009). Furthermore, blooms with high cell numbers can have a significant effect on the formation of disinfection byproducts after oxidation with chlorine (Rositano et al., 2001; Rodríguez et al., 2007; Zamyadi et al., 2011 and Zamyadi et al., 2012a).

Removal of phytoplankton is a challenge during conventional water treatment as it is often inhibited by various factors such as: (i) the specific phytoplankton species present, (ii) the concentration of the phytoplankton in the source water, (iii) the optimisation (or lack thereof) of the coagulation, flocculation and sedimentation unit processes as well as (iv) the effectiveness of the sand filtration process. It is therefore important to monitor phytoplankton and their related organic compounds, not only in the source water, but also in the drinking water (Swanepoel et al., 2008a), and to get a clear understanding of the efficacy of conventional treatment processes (i.e. different unit processes) in removing phytoplankton and their related organic compounds from the source water. The objectives of this study were to (i) identify problem-causing phytoplankton 
genera in source water supplied to the treatment plant and (ii) to investigating the efficacy of conventional water treatment processes in removing problematic phytoplankton and associated organic compounds. Therefore, this study focused on phytoplankton groups like Cyanophyceae (genera: Microcystis, Anabaena and Oscillatoria) and Dinophyceae (genus: Ceratium), which are known to produce unpleasant (e.g. taste and odour) and harmful (e.g. cyanotoxins) organic compounds (Newcombe, 2009; Swanepoel et al., 2008a; Du Preez et al., 2007)

\section{EXPERIMENTAL}

\section{Area of investigation}

The study was undertaken at South Africa's largest drinking water treatment plant (DWTP), situated outside Vereeniging, south of Johannesburg, South Africa. The DWTP purifies water from the Vaal Dam, using conventional treatment processes (coagulation, flocculation, sedimentation, sand filtration and chlorination) to treat approximately 3000 $\mathrm{M} /$ /day. The treatment plant simultaneously uses hydrated lime, activated sodium silicate and organic coagulants as part of the coagulation process which specifically enhances the removal of phytoplankton and other particulate matter. Optimum hydrated lime ( $\pm 60 \mathrm{mg} / \mathrm{\ell})$ and activated sodium silicate $( \pm 1.6 \mathrm{mg} / \ell)$ dosages under high-energy mixing conditions are based on source water quality and jar stirring tests. The optimum dosage of organic coagulants under high-energy mixing can vary between $3-10 \mathrm{mg} / \ell$, depending on source water quality and polymer type. After coagulation, flocculation and sedimentation, water is channelled to filter houses containing 64 rapid gravity sand filters (size of each sand filter: $164 \mathrm{~m}^{2}$ ), which run on $36 \mathrm{~h}$ backwash cycles during normal operations. After the sand filtration process, chlorine disinfection is applied to produce pathogen-free drinking water. During this study, the initial chlorine dosages were between 1 and $4 \mathrm{mg} / \ell$ (depending on source water quality), while free chlorine residual varied between 1 and $2.5 \mathrm{mg} / \ell$ after $20 \mathrm{~min}$ of contact time. Secondary disinfection by chloramination was achieved by dosing chlorine and ammonia in the correct mass ratio of not less than 4:1 and forming monochloramine in situ (Rand Water, 2001).

\section{Sampling}

Source water samples were collected from the forebay (a $500 \mathrm{Me}$ storage reservoir before the treatment plant) after a $20 \mathrm{~km}$ open canal supplying the DWTP with source water from the Vaal Dam. Additional samples were also collected from sampling localities during different stages of the conventional treatment processes, namely: (i) after sedimentation, (ii) after filtration and (iii) in the final water (after chlorination). Sampling was performed twice a month, from February 2008 to March 2010. These samples were collected according to the sample collection procedures for the analytical laboratories at Rand Water Analytical Services (a South African National Accreditation System (SANAS) accredited laboratory). Samples were collected $30 \mathrm{~cm}$ from the surface in the source water as well as after sedimentation in the flumes on the way to the sand filters. Samples for 'after filtration' and 'in the final water' were collected from continuous flowing taps, specifically designed for sampling. These samples were analysed for phytoplankton (identification as well as enumeration) together with related organic substances.

\section{Laboratory analyses}

Collected phytoplankton samples were fixed with Lugol's solution or formaldehyde ( $2 \%$ final concentration). These samples were used for the quantitative and qualitative phytoplankton analyses. Phytoplankton analyses were performed at the algae laboratory of the Department of Environmental Sciences and Development of the North-West University (Potchefstroom Campus), by using the sedimentation technique (Lund et al., 1958).

The concentrations of the following organic compounds: total photosynthetic pigments (TPP as measured in $\mu \mathrm{g} / \ell$ chlorophyll-665) and geosmin were measured over a period of 2 years (February 2008 to March 2010). These analyses were performed at Rand Water Analytical Services according to SANAS-accredited laboratory methods (Swanepoel et al., 2008b).

\section{Statistical analysis}

The canonical correspondence analysis (CCA) was performed on data obtained from the source water using CANOCO version 4.5 (Ter Braak, 1996). The CCA ordinations were used to determine which organic compounds were associated with phytoplankton groups in the source water.

A single factor analysis of variance (ANOVA) was performed to determine if there is a statistically significant difference between the average counts of phytoplankton concentrations enumerated at 4 different sampling localities (source water, after sedimentation, after filtration and final water). T-tests were used to further clarify which processes were significant in removing the phytoplankton concentrations. The level of significance for all statistical analyses was set at 0.05 ( $p$-value) and the hypotheses were stated separately for each analysis with the hypothesised difference equal to zero.

\section{RESULTS AND DISCUSSION}

The phytoplankton community found in the source water supplied to the DWTP consisted of 7 phytoplankton groups, namely; Bacillariophyceae, Cyanophyceae, Chlorophyceae, Chrysophyceae, Cryptophyceae, Dinophyceae and Euglenophyceae (Table 1). The Cyanophyceae dominated the phytoplankton community throughout the entire investigation period. The genera Anabaena, Microcystis and Oscillatoria dominated the composition of the Cyanophyceae group, which are represented in relation to the total phytoplankton biomass (concentration) in Fig. 1. The highest percentage composition for Anabaena was recorded at between 90 and $100 \%$ on different occasions (dominant for 19 months of the study period). The highest percentage composition for Microcystis was $86 \%$ (dominant for 5 months), while Oscillatoria only dominated the percentage composition in May 2009 (86\% of the total composition). It is evident that the Cyanophyceae genera have the potential to dominate the phytoplankton community during almost all seasons. Anabaena genera are more likely to occur during summer and spring (September to February), while Microcystis occur mostly during autumn and winter (March to August) as shown by the canonical correspondence analysis (Fig. 2). Phytoplankton genera (especially members of the Cyanophyceae) usually undergo a fairly predictable annual cycle, but some genera grow exponentially and form blooms in the source water (Vaulot, 2001; Hart and Wragg, 2009). The high percentage composition of Anabaena, Microcystis and 


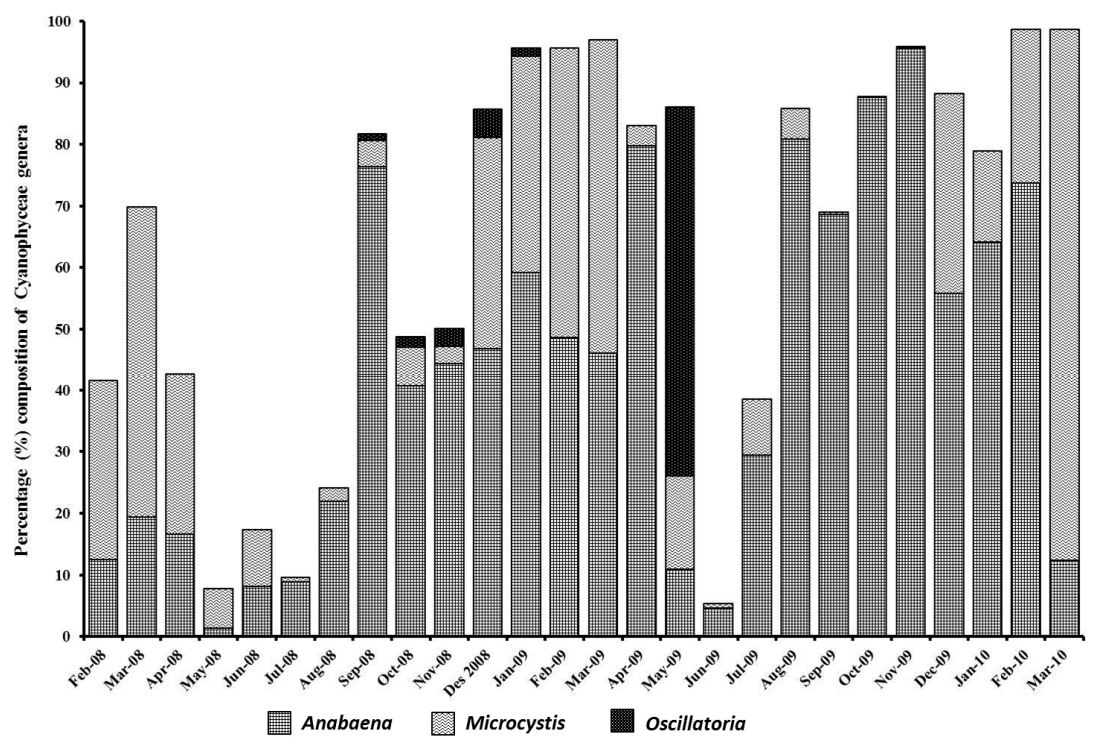

Figure 1

The percentage dominance of the three Cyanophyceae genera (Anabaena, Microcystis and Oscillatoria) in relation to the total phytoplankton biomass/ concentration in the source water detected during the study period (February 2008 to March 2010)

\begin{tabular}{|l|l|}
\hline \multicolumn{2}{|c|}{$\begin{array}{c}\text { TABLE } 1 \\
\text { Phytoplankton genera identified in the source water } \\
\text { to the conventional DWTP during the study period } \\
\text { Fe08 - March 2010 }\end{array}$} \\
\hline BACILLARIOPHYCEAE & CHLOROPHYCEAE \\
\hline Aulacoseira & Actinastrum \\
\hline Asterionella & Ankistrodesmus \\
\hline Cyclotella & Carteria \\
\hline Cymbella & Chlamydomonas \\
\hline Fragilaria & Closterium \\
\hline Gomphonema & Cosmarium \\
\hline Gyrosigma & Coelastrum \\
\hline Melosira & Dictyosphaerium \\
\hline Navicula & Monoraphidium \\
\hline Nitzschia & Oocystis \\
\hline Stephanodiscus & Pediastrum \\
\hline & Scenedesmus \\
\hline CYANOPHYCEAE & Staurastrum \\
\hline Anabaena & Tetraedron \\
\hline Microcystis & Tetrastrum \\
\hline Oscillatoria & \\
\hline & CRYPTOPHYCEAE \\
\hline CHRYSOPHYCEAE & Cryptomonas \\
\hline Dinobryon & Rhodomonas \\
\hline Mallomonas & \\
\hline Synura & EUGLENOPHYCEAE \\
\hline & Euglena \\
\hline DINOPHYCEAE & Phacus \\
\hline Ceratium & Strombomonas \\
\hline Peridinium & Trachelomonas \\
\hline
\end{tabular}

a high phytoplankton concentration (which is responsible for associated organic products) enters the water treatment plant (Swanepoel et al., 2008a, b). The organic compounds associated with phytoplankton (especially Cyanophyceae) may affect the drinking water quality rather severely, because of (i) their potential to produce taste and odour compounds making drinking water aesthetically displeasing (Dixon et al., 2011), (ii) producing toxic substances which may be harmful (even lethal) to consumers and/or (iii) being precursors in the formation of disinfection by-products during chlorination (Van der Walt et al., 2009).

In Fig. 2 , the first axis ( $x$-axis) explains $59 \%$ of the variance in the data (TPP, $\mathrm{PO}_{4}$, temperature and DOC). Furthermore, the second axis ( $y$-axis) explains an additional $41 \%$ of the variance in the data (silica, dissolved inorganic nitrogen, turbidity, $\mathrm{pH}$, hardness, chemical oxygen demand (COD), alkalinity, geosmin and conductivity).

The taste and odour compound geosmin correlates positively with Anabaena during summer and spring (Fig. 2). Anabaena and other Cyanophyceae genera are known to produce geosmin and release it into the water when cell lyses occur during the water treatment process - causing earthycorn-musty tastes and odours in potable water (AWWA, 2004). Ceratium (a member of the Dinophyceae) correlated positively with the TPP concentration in the source water during the autumn and winter months (Fig. 2), indicating that the TPP concentration consisted mostly of chlorophyll produced by Ceratium cells. The amount of chlorophyll per unit specific cell volume as mean chlorophyll- $a$ content, for the Cyanophyceae species Anabaena circinalis, Oscillatoria agardhii v. isothrix and Microcystis aeruginosa, was 7.3, 5.2 and $4.9 \mu \mathrm{g}$ chl.- $a \mathrm{~mm}^{-3}$, respectively, and $5.4 \mu \mathrm{g}$ chl.- $a \mathrm{~mm}^{-3}$ for Ceratium hirundinella (Reynolds, 1984). The cell size (up to $450 \mu \mathrm{m}$ long and 30-100 $\mu \mathrm{m}$ wide) and mean chlorophyll (5.4 $\mu \mathrm{g}$ chl. $\left.-a \mathrm{~mm}^{-3}\right)$ per Ceratium hirundinella cell is enough evidence to prove that a Ceratium hirundinella cell contributes significantly to the photosynthetic pigment content in water (e.g. chlorophyll-a).

The average variation of the most problematic groups, namely the Cyanophyceae and Dinophyceae, are presented in Figs. 3a and 3b, respectively. Seasonal, and in some cases sporadic, occurrences of high Cyanophyceae concentrations and associated organic compounds (e.g. cyanotoxins and 


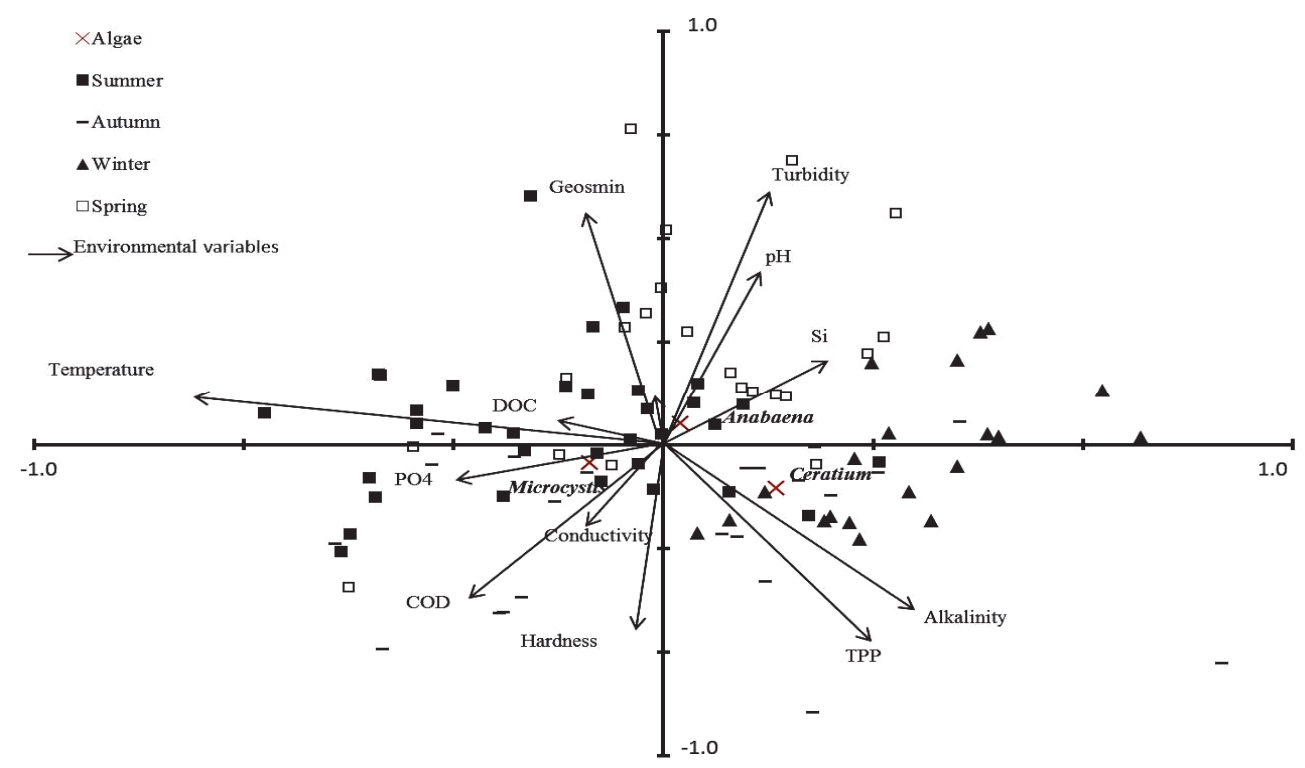

\section{Figure 2 \\ The canonical correspondence analysis (CCA) ordination showing the important principal environmental components and organic compounds that correlate with the major phytoplankton genera in the source water supplied to the DWTP studied}

geosmin) in source water may add to challenges during the treatment process (Du Preez and Van Baalen, 2006). Source water supplied to South Africa's largest conventional DWTP can be considered as a source with low Cyanophyceae (cyanobacteria) concentrations and subsequently low risks of cyanobacteria problems (e.g. cyanotoxins) when compared to source waters supplied to DWTP in Quebec, Canada (Zamyadi et al., 2012b), Bahia Blanca, Argentina (Echenique et al., 2001) and Queensland, Australia (Khan et al., 2001). The seasonal average concentrations of Cyanophyceae in the source were relatively low throughout the investigation period (maximum 1185 cells/ $\mathrm{m} \ell$ ) in comparison to blooms (cyanobacteria concentrations $>$ 1000000 cells $/ \mathrm{ml}$ ) recorded in source water supplied to DWTP in Quebec, Canada (Zamyadi et al., 2012b). Seasonal average concentrations detected in the final water indicated effective removal $(<70$ cells $/ \mathrm{m} \ell)$, with a percentage removal above $90 \%$ during almost all seasons (except during autumn 2008) (Fig. 3a). The highest seasonal average was recorded during spring 2008 (> 1000 cells $/ \mathrm{ml})$ and the lowest during winter $2009(<200$ cells $/ \mathrm{ml})$. These observations indicate that the Cyanophyceae concentrations in the source water did not have a major negative influence on the conventional water treatment process to effectively remove the cells (mostly in colonies and filaments) from the water (Fig. 3a). However, the percentage of cells penetrating $(5-10 \%)$ into the final drinking water in the current study were relatively low when compared to cases in Bahia Blanca, Argentina (270-2 475 cells/ml) and Queensland, Australia (11 230 cells/ml) (Hoeger et al., 2005).

The average seasonal concentrations for Dinophyceae (consisting mostly of Ceratium in the source water) were also low (maximum approximately 9 cells $/ \mathrm{ml}$ ); however, the percentage penetration into the final water can be considered as high when compared to the concentration in the source water. The overall percentage removal for this group was low during the investigation period $(0 \%$ removal was observed during the summer of 2010, Fig. 3b). Seasons where $100 \%$ removal is indicated may be due to low concentrations in the source water (spring-summer 2008/2009).

The conventional water treatment processes were not able to remove even low Dinophyceae concentrations from the source water, which may pose a challenge to the DWTP when Dinophyceae concentrations may increase in the source water (as predicted by Swanepoel et al., 2008a). These observations therefore confirm that the conventional water treatment processes are not suitable to treat water with high Ceratium concentrations (Fig. 3b). Ceratium cells are known to disrupt coagulation, flocculation and sedimentation processes (Swanepoel et al., 2008a) and are also responsible for water treatment problems such as filter clogging as well as impacting on aesthetic water quality. These relatively large Dinophyceae cells (Van Ginkel et al., 2001 and Janse van Vuuren et al., 2006) are known to cause extensive water treatment problems even in relatively low concentrations due to their large cell size.

Swanepoel and Du Preez (2010) speculated that the presence of Ceratium in the source water may be one of the factors that cause chlorophyll breakthrough into the final water. The total photosynthetic pigment (TPP) concentrations (as expressed in $\mu \mathrm{g} / \ell$ chlorophyll-665) in the source water, as displayed in Fig. 4, followed the same trends as the average seasonal counts of the Dinophyceae (Fig. 3b), indicating that the total photosynthetic pigments (TPP) are mostly produced by the large-celled Dinophyceae. The CCA ordination diagram (Fig. 2) also shows a positive correlation between TPP and Ceratium, emphasising this observation. In the final water TPP was shown to have been removed effectively (ranging from $96-100 \%$ removal) during the study period. It should be noted, however, that the phytoplankton cells may not have been removed effectively (Figs. $3 \mathrm{a}$ and $3 \mathrm{~b}$ ), but rather that the TPP (Fig. 4) were oxidised by the chlorine and therefore not detected in the final drinking water (Van der Walt et al., 2009).

Van der Walt (2010) investigated the impact of conventional water treatment processes on Ceratium cells and found that cells can be rendered immobile during pre- or intermediate chlorination which may assist the coagulation process and increase the removal efficiency for Ceratium by conventional water treatment processes. Pre- or intermediate chlorination should however be implemented with utmost caution at conventional DWTP, since chlorination is known to aid in the lysis of cells, where organic compounds are released into the water and subsequently cannot be removed without advanced treatment options such as ozone or activated carbon adsorption.

Geosmin is a secondary metabolite produced by cyanobacteria and has been reported as imparting an earthy or musty taste and odour to drinking water (Van Ginkel and Conradie, 


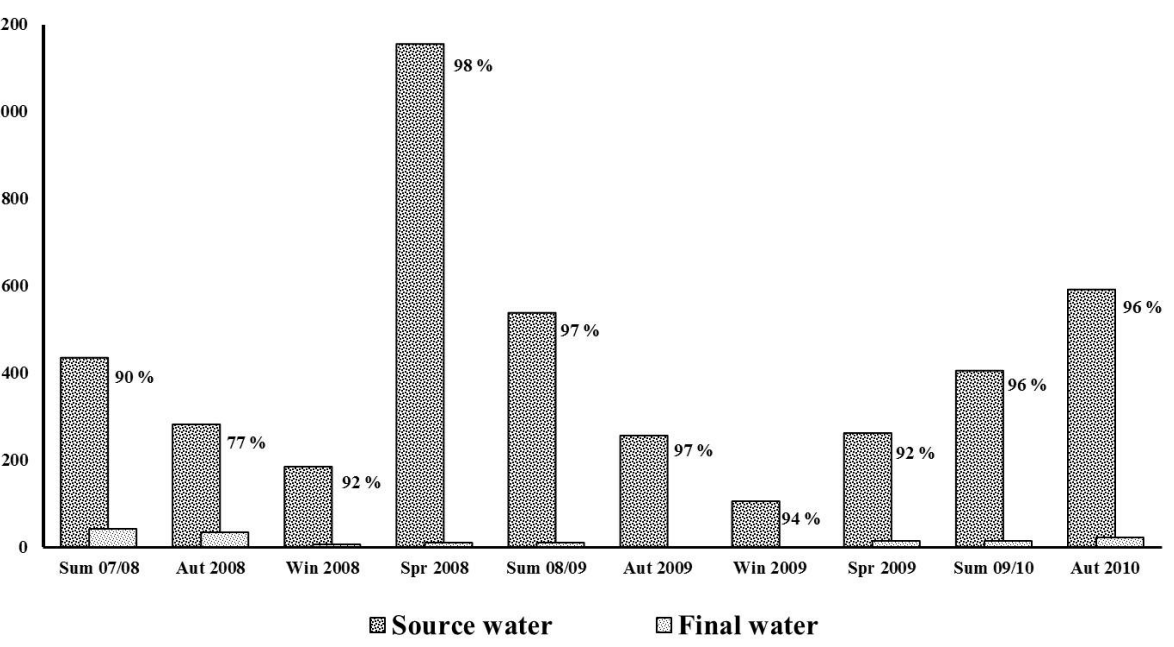

Figure $3 a$

The percentage (\%) removal of Cyanophyceae concentrations (average seasonal) by the conventional water treatment processes.

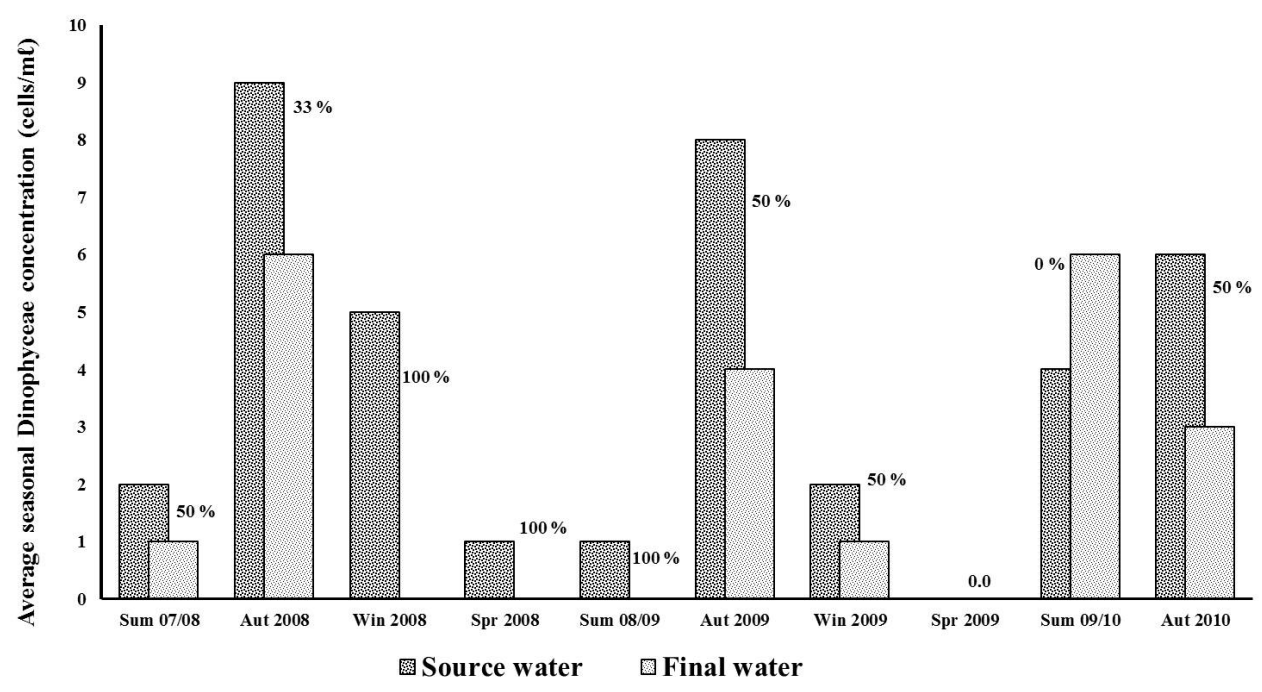

Figure $3 \boldsymbol{b}$

The percentage (\%) removal of Dinophyceae concentrations (average seasonal) by the conventional water treatment processes.

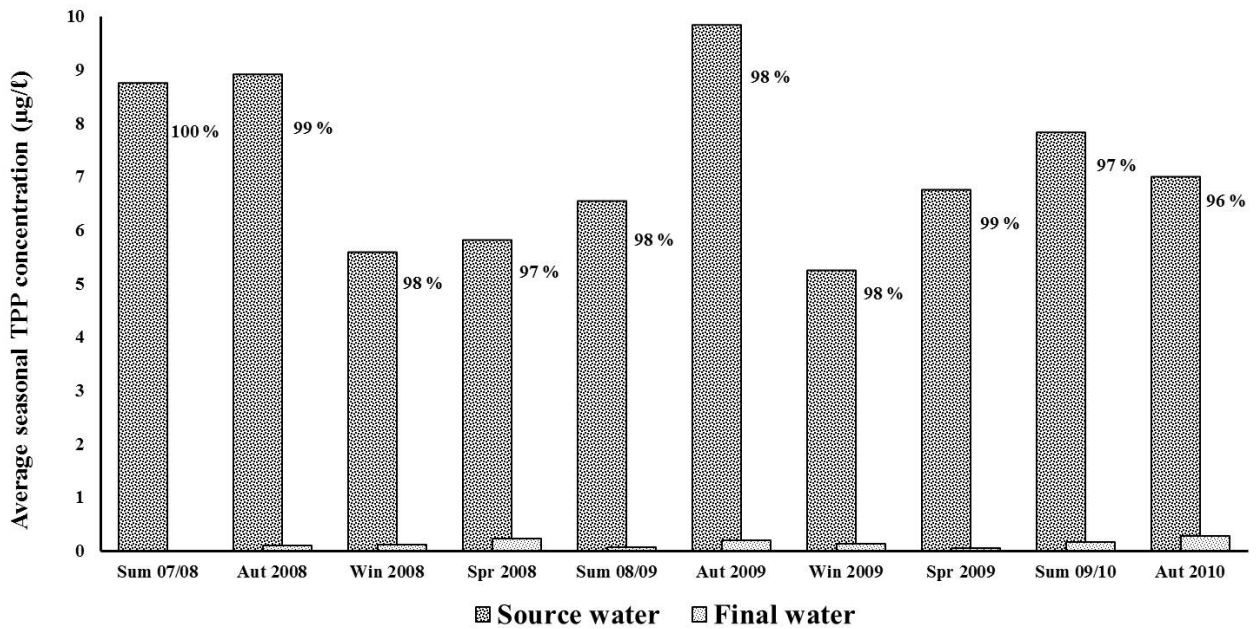

\footnotetext{
Figure 4

Percentage (\%) removal of seasonal average concentrations of TPP by the treatment processes
}

2001; Downing and Van Ginkel, 2004; Swanepoel et al., 2008b). Conventional drinking water treatment processes usually achieve minimal removal of geosmin and rarely remove these compounds to a commonly accepted organoleptic detection

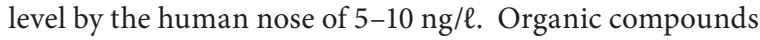
like geosmin are usually only removed by advanced treatment like adsorption to powered activated carbon, granular activated carbon, or oxidation by ozone when released into the water (Westerhoff et al., 2005). Therefore, conventional drinking water treatment operators and managers should always aim to remove Cyanophyceae cells intact during coagulation, flocculation and sedimentation before cells lyse and organic compounds are released into the water. This seems to have been the case during the current study where it is evident that the geosmin levels detected in the drinking water were below the accepted organoleptic detection levels (Fig. 5b) as stated by 


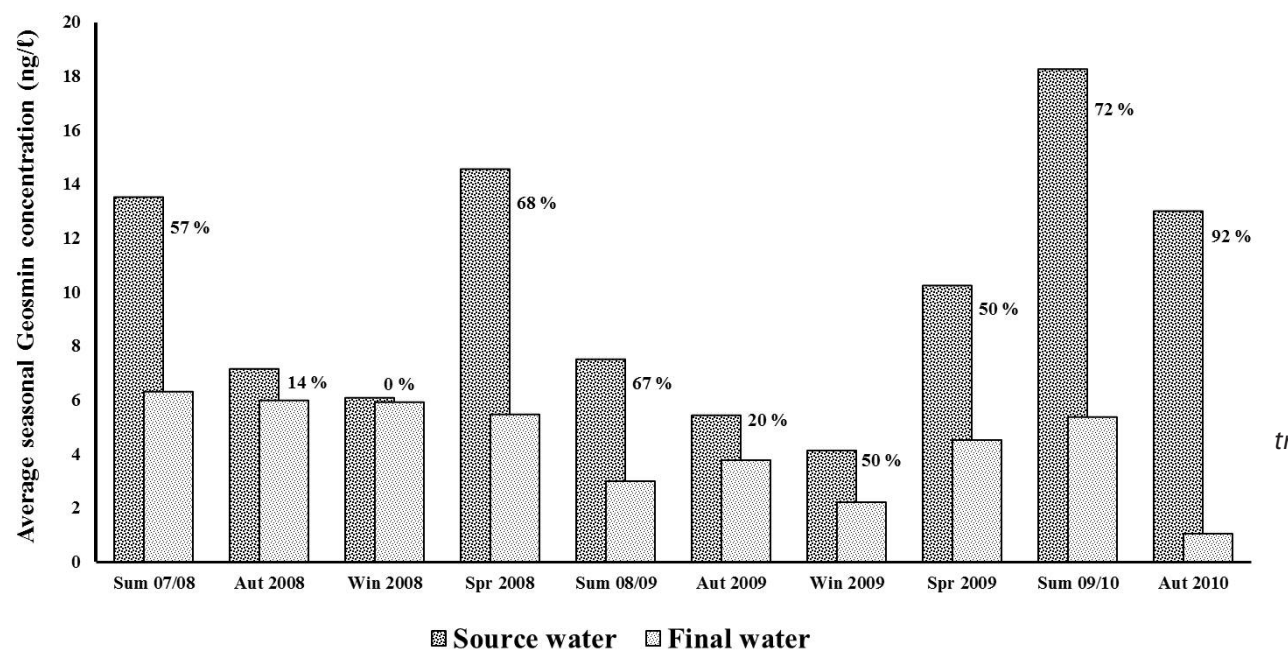

Figure 5a

Percentage (\%) removal of seasonal average concentrations of geosmin by the treatment processes.

Final drinking water

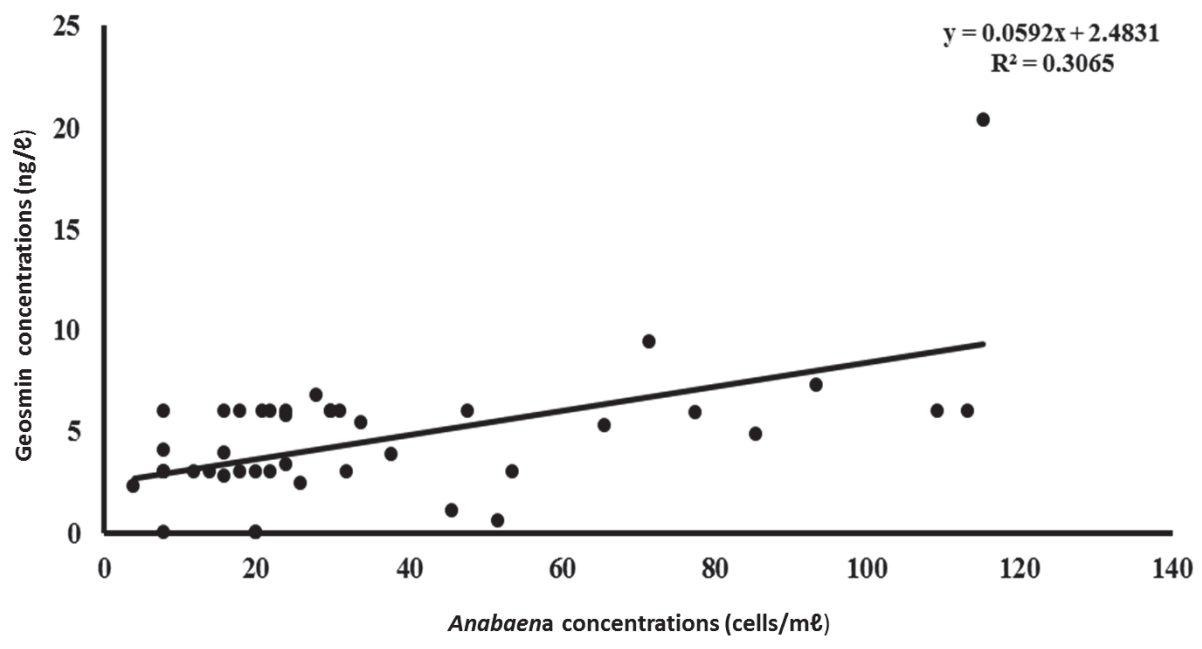

Figure $5 b$

The correlation between Anabaena (cells/me) and geosmin $(n g / \ell)$ in the final drinking water.

Westerhoff et al. (2005), except for one occasion (1 December 2009) where $20 \mathrm{ng} / \ell$ was detected in the final water.

The geosmin content that was measured in both the source and final drinking water may have been produced by the Cyanophyceae genus Anabaena (Figs. 2, 3a, 5a, 5b). The average seasonal concentrations of geosmin in the source water have shown a decrease from summer towards winter, with an increase in spring of each year (2008 and 2009), which was expected since the Cyanophyceae (especially Anabaena spp.) concentrations were also slightly higher during the same seasons (Figs. 1, 5a).

The best correlation of geosmin with phytoplankton was found between Anabaena and geosmin (Fig. 5b) with a $R^{2}$ value of 0.31 indicating a positive relationship between Anabaena cell numbers and geosmin concentration. Although this is not a very good correlation it is still regarded as sufficiently significant to indicate that Anabaena genera are mainly responsible for geosmin production.

Removal of phytoplankton by water treatment processes is difficult because of their small size and the low specific gravity (Ma and Liu, 2002). To get a clear understanding of which conventional water treatment processes were effective for the removal of specific problem-causing phytoplankton (as well as their associated organic compounds), the performance of the full-scale treatment process was evaluated (Table $3 \mathrm{a}$ and $3 \mathrm{~b}$ ). Evaluation of the full-scale processes includes coagulation, flocculation and sedimentation, as represented by the difference between sampling points named 'source water' and 'after sedimentation', sand filtration as represented by the difference between the sampling points 'after sedimentation' and 'after filtration', as well as chlorination as represented by the difference between the sampling points named 'after filtration' and 'final water'. This evaluation was aimed to indicate which processes were effective in removing certain phytoplankton species and organic compounds and which processes potentially needed better optimisation.

Seven major phytoplankton groups, namely Bacillariophyceae, Cyanophyceae, Chlorophyceae, Chrysophyceae, Cryptophyceae, Dinophyceae and Euglenophyceae occurred in the source water supplied to the DWTP. Each of these groups contains specific characteristics that add to the challenges and removal difficulties for the conventional water treatment process (especially that of coagulation and flocculation). Some of the main characteristics of these phytoplankton genera that impact on the treatment process are morphology, motility, surface charge and cell density (Henderson et al., 2008).

In Table $3 \mathrm{a}$, the ANOVA results comparing the overall water treatment processes (coagulation, flocculation, sedimentation, filtration and disinfection/chlorination) are displayed. This was performed for each individual genus investigated as well as for the two organic compounds associated with it (TPP and geosmin). 
Anabaena Microcystis and Ceratium were effectively removed by the conventional water treatment processes (Table 3a). However, no statistically significant difference was observed after filtration (Table 3b), (implying during the chlorination step), since chlorination is not aimed at removing phytoplankton cells but rather at disinfecting the final drinking water by killing pathogenic organisms.

For the removal of Oscillatoria on the other hand, there was not enough evidence to suggest statistically significant removal during the conventional water treatment process (Table $3 \mathrm{a}$ ). The filamentous Oscillatoria genera occurred on only a few occasions and were not present at all sampling localities, which might be a major factor contributing to the lack of evidence.
Geosmin and TPP showed statistically significant removal during the overall conventional water treatment process (coagulation, flocculation, sedimentation and filtration; Table $3 \mathrm{a}$ ). This may be an indication that phytoplankton (especially cyanobacteria) cells were still intact, where organic compounds are trapped inside the cells and removed when phytoplankton cells are removed.

To evaluate the individual processes and their capability to remove phytoplankton and associated organic material, $\mathrm{t}$-tests were performed between data from each consecutive process to determine if a statistically significant difference exists between the water quality before and after each unit process (Table $3 \mathrm{~b}$ ).

\begin{tabular}{|c|c|c|c|c|c|c|c|}
\hline \multicolumn{8}{|c|}{$\begin{array}{l}\text { TABLE 3a } \\
\text { ANOVA results indicating statistically significant differences (or lack thereof) between } 4 \text { sets of } \\
\text { data obtained from the source water, after sedimentation, after filtration and in the final water. } \\
\text { The level of significance for statistical analysis was set at } p=0.05 \text {. }(\checkmark) \text { Statistically significant } \\
\text { difference; (X) Not enough evidence to suggest any statistically significant difference. }\end{array}$} \\
\hline & & \multicolumn{4}{|c|}{ Sampling localities } & \multirow{2}{*}{\multicolumn{2}{|c|}{$\begin{array}{c}\begin{array}{c}\text { Statistically significant } \\
\text { difference }(\checkmark)\end{array} \\
\text { Not enough evidence }(X) \\
p \text {-value }\end{array}$}} \\
\hline \multicolumn{2}{|c|}{$\begin{array}{l}\text { Phytoplankton and organic } \\
\text { compounds }\end{array}$} & $\begin{array}{l}\text { Source } \\
\text { water }\end{array}$ & $\begin{array}{c}\text { After } \\
\text { sedimen- } \\
\text { tation }\end{array}$ & $\begin{array}{c}\text { After } \\
\text { filtration }\end{array}$ & $\begin{array}{l}\text { Final } \\
\text { water }\end{array}$ & & \\
\hline \multicolumn{8}{|c|}{ Cyanophyceae } \\
\hline Anabaena & (cells/m $/$ ) & 751 & 194 & 25 & 15 & $1.11 \times 10^{-10}$ & $\checkmark$ \\
\hline Microcystis & $($ cells/ml) & 289 & 53 & 7 & 2 & $4.72 \times 10^{-08}$ & $\checkmark$ \\
\hline Oscillatoria & (cells/ml) & 29 & 0 & 2 & 0 & $6.94 \times 10^{-02}$ & $\mathrm{X}$ \\
\hline \multicolumn{8}{|l|}{ Dinophyceae } \\
\hline Ceratium & (cells/ml) & 9 & 5 & 1 & 2 & $1.39 \times 10^{-02}$ & $\checkmark$ \\
\hline \multicolumn{8}{|c|}{ Organic compounds } \\
\hline Geosmin & $(\mathrm{ng} / \ell)$ & 8.95 & 6.20 & 4.56 & 4.28 & $1.4 \times 10^{-04}$ & $\checkmark$ \\
\hline TPP & $(\mu \mathrm{g} / \ell)$ & 6.95 & 1.70 & 0.65 & 0.13 & $8.9 \times 10^{-54}$ & $\checkmark$ \\
\hline
\end{tabular}

\begin{tabular}{|c|c|c|c|c|}
\hline \multicolumn{5}{|c|}{$\begin{array}{l}\text { Results of T-tests performed to indicate which conventional water treatment processes were } \\
\text { effective }(\checkmark) \text { in removing phytoplankton and organic compounds, or, alternatively, which stage } \\
\text { of the water treatment process could not be shown to be effective }(X)\end{array}$} \\
\hline \multirow{2}{*}{\multicolumn{2}{|c|}{$\begin{array}{l}\text { Phytoplankton and organic } \\
\text { compounds }\end{array}$}} & \multicolumn{3}{|c|}{$\begin{array}{l}\text { Sampling localities }(\mathrm{SW}=\text { source water, } \mathrm{AS}=\text { after sedimentation, } \\
\qquad \mathrm{AF}=\text { after filtration and } \mathrm{FW}=\text { final water })\end{array}$} \\
\hline & & SW-AS & AS-AF & AF-FW \\
\hline \multicolumn{5}{|c|}{ Cyanophyceae } \\
\hline Anabaena & $($ cells/ml) & $\checkmark$ & $\checkmark$ & $\mathrm{X}$ \\
\hline Microcystis & (cells/me) & $\checkmark$ & $\checkmark$ & $\mathrm{X}$ \\
\hline Oscillatoria & $($ cells/ml) & \multicolumn{3}{|c|}{$\begin{array}{l}\text { ANOVA results (Table } 3 \mathrm{a} \text { ) indicated not enough evidence to } \\
\text { suggest any statistically significant differences, therefore no } \\
\text { T-tests were performed between } 4 \text { sets of data }\end{array}$} \\
\hline \multicolumn{5}{|l|}{ Dinophyceae } \\
\hline Ceratium & (cells/ml) & $\mathrm{X}$ & $\checkmark$ & $\mathrm{X}$ \\
\hline \multicolumn{5}{|c|}{ Organic compounds } \\
\hline Geosmin & $(\mathrm{ng} / \ell)$ & $\mathrm{X}$ & $\mathrm{X}$ & $\mathrm{X}$ \\
\hline TPP & $(\mu \mathrm{g} / \ell)$ & $\checkmark$ & $\checkmark$ & $\checkmark$ \\
\hline
\end{tabular}


Although coagulation, flocculation and sedimentation were effective in removing the Cyanophyceae, specifically Anabaena and Microcystis (as indicated by SW-AS in Table 3b) it was not effective in removing Ceratium. However, Anabaena and Microcystis were removed effectively during coagulation, flocculation and sedimentation as well as during sand filtration. No statistically significant difference was found after filtration (implying during the chlorination step), since phytoplankton cells are not removed during disinfection, only discoloured (oxidised).

Ceratium cells were not removed during coagulation, flocculation and sedimentation, suggesting that the coagulant chemical (or the coagulant dosage) was not appropriate for Ceratium removal. This also supports the speculation by Swanepoel and Du Preez (2010) that Ceratium disrupts the coagulation, flocculation and sedimentation unit processes, and avoids coagulation, flocculation and sedimentation, because of their large cell size and unique morphological characteristics. Therefore, it may be advisable to implement regular jar stirring test experiments when Ceratium occur at high concentrations in the source water to ensure the effective removal of all phytoplankton genera (specifically problem-causing genera). Ceratium genera were, however removed effectively during filtration (as indicated by AS-AF in Table 3b). Due to their relatively large cell size (Van Ginkel et al., 2001 and Janse van Vuuren et al., 2006), Ceratium can be retained in the sand filters effectively. This however poses a challenge to the DWTP, since Ceratium are known to cause extensive filter clogging problems (Palmer, 1980), decreasing the filter run times and increasing the cost of water treatment significantly.

Optimising the coagulation, flocculation and sedimentation unit processes can remove phytoplankton cells and therefore a large proportion of metabolites such as total photosynthetic pigments (TPP), 2methylisoborneol (2-MIB) and geosmin, before cells lyse and release their organic compounds into the water, after which these will be impossible to remove with conventional treatment methods (Ho and Newcombe, 2010). However, not enough evidence exists to suggest effective removal of geosmin during this investigation. This may be an indication that the conventional water treatment processes were not able to adsorb or oxidise the geosmin during purification, but may also be due to relatively low concentrations of geosmin (an average of $8.95 \mathrm{ng} / \ell$ ) in the source water during the study period. However, should geosmin-producing cells be removed intact (as was displayed during this investigation, Table 3a) the majority of geosmin can be removed by removing the Cyanophyceae cells within which it occurs. Sithole et al. (2007) observed a high percentage removal of geosmin during investigations into a conventional DWTP by using $\beta$ cyclodextrin polymers, indicating that the choice of coagulant chemical can play a significant role in removing organic material from the source water. This is especially important when chemicals of a corrosive nature (e.g. lime with a $\mathrm{pH}$ of $>9$ ) are used as coagulants, as these might lyse phytoplankton cells and release the organic compounds from inside the cells.

The overall removal of total photosynthetic pigments (TPP) by the conventional water treatment processes were effective; this may be due to the fact that TPP remained within the phytoplankton cells throughout the treatment process (Tables $3 \mathrm{a}$ and $3 \mathrm{~b}$ ). Ceratium contributed significantly to the TPP content that was measured in the water during the investigation, which may confirm the robustness of the Ceratium cells and/or their ability to remain intact and avoid the impact of treatment. Preventing cell lysis during treatment should always be an objective during conventional drinking water treatment to remove organic compounds such as TPP and geosmin effectively.

\section{CONCLUSIONS}

South Africa's largest conventional water treatment plant uses conventional water treatment processes to purify source water from the Vaal Dam. The water treatment plant operators dose hydrated lime, activated sodium silicate and organic coagulants simultaneously as part of the coagulation process. Rapid sand filtration is the final barrier to remove suspended material before chlorine disinfection. Source water supplied to the conventional water treatment plant contains a phytoplankton (algae and cyanobacteria) community that consists of 7 major groups, which are sub-divided into genera. The Cyanophyceae group was identified as the dominant group, which consisted of Anabaena, Microcystis and Oscillatoria as well as the genus Ceratium, belonging to the Dinophyceae group. Anabaena and Ceratium were identified as problemcausing genera during this investigation, due to (i) their relatively high abundance in the source water, (ii) Anabaena's potential to produce harmful cyanotoxins as well as taste and odour organic compounds (e.g. geosmin), and (iii) Ceratium's ability to clog sand filters and produce fishy odours in the drinking water. Furthermore, Ceratium contributed significantly to the organic content (e.g. TPP and chlorophyll-a) in the water and have the potential to interfere with coagulation and flocculation unit processes when coagulant dosages are not optimised. It has become evident from this study that the conventional water treatment plant:

- Achieves high percentage (96-100\%) removal of cyanobacteria cells during the production of drinking water and subsequently reduce the risks of cyanotoxins, taste and odours to drinking water consumers.

- Removes Ceratium cells effectively during the sand filtration stage; however when cells are present in large numbers in the source water it may put major strain on sand filters and reduce sand filter run-times.

- Was not effective in removing geosmin (associated with mainly Anabaena), which may be a result of cyanobacteria cell lyses (releasing organic compounds), since good removal of cyanobacteria cells was recorded. When cyanobacteria concentrations in the source water increase ineffective removal of geosmin may increase taste and odour problems in the drinking water.

- Effectively removed total photosynthetic pigments (TPP) by all different treatment processes during the investigation period, which may be a result of relatively good phytoplankton cell removal during water treatment and active oxidation by chlorine during the disinfection stage.

Phytoplankton genera and associated organic compounds are able to avoid removal by different conventional unit processes (e.g. coagulation); therefore, optimisation of each unit process plays an important role in purifying water to a quality that meets drinking water standards and guidelines. The development and implementation of incident management frameworks (e.g. cyanobacterial or geosmin incident management frameworks) can be effective to help managers and operators of conventional DWTP to react when high cyanobacteria concentrations occur in source water supplied to the water treatment plant. This may add to the confidence in drinking water quality and the safety of consumers. 


\section{ACKNOWLEDGEMENTS}

The North-West University (NWU) and Rand Water are acknowledged for their facilities and support to the project. Dr A Venter, Prof S Barnard, Dr AJH Pieterse and Dr Sanet Janse van Vuuren from NWU are thanked for moral support and scientific input. Prof Leon van Rensburg from NWU is thanked for financial support to the project and Mr Lungelo Mkhize from Rand Water's Information Management Department is thanked for statistical analyses of data.

\section{REFERENCES}

AWWA (2004) Algae Detection and Removal Strategies for Drinking Water Treatment Plants. Report number: 90971. AWWA Research Foundation, Denver. $466 \mathrm{pp}$.

DIXON MK, RICHARD Y, HO L, CHOW CWK, O'NEILL BK and NEWCOMBE G (2011) A coagulation-powered activated carbonultrafiltration - Multiple barrier approach for removing toxins from two Australian cyanobacterial blooms. J. Hazardous Mater. 186 1553-1559.

DOWNING T and VAN GINKEL CE (2004) Cyanobacterial monitoring 1990-2000: Evaluation of SA Data. WRC Report No. 1288/1/04. Water Research Commission, Pretoria.

DU PREEZ HH and VAN BAALEN (2006) Generic incident management framework for toxic blue-green algal blooms, for the application by potable water suppliers. WRC Report No. TT 263/06. Water Research Commission, Pretoria. 65 pp.

DU PREEZ HH, SWANEPOEL A, VAN BAALEN L and OLDEWAGE A (2007) Cyanobacterial Incident Management Frameworks (CIMFs) for application by drinking water suppliers. Water $S A$ 33 643-652.

ECHENIQUE R, FERRARI L and GONZALEZ D (2001) Cyanobacterial blooms in Paso de las Piedras reservoir (Buenos Aires, Argentina). Harmful Algae News 223.

HART RC and WRAGG PD (2009) Recent bloom of the dinoflagellate Ceratium in Albert Falls Dam (KZN): History, causes, spatial features and impacts on a reservoir ecosystem and its zooplankton. Water SA 35 (4) 455-468.

HEISLER J, GILBERT PM, BURKHOLDER JM, ANDERSON DM, COCHLAN W, DENNISON WC, DORTCH Q, GOBLER CJ, HEIL CA, HUMPHRIES E, LEWITUS A, MAGNIEN R, MARSHALL HG, SELLNER K, STOCKWELL DA, STOECKER DK and SUDDLESON M (2008) Eutrophication and harmful algal blooms: A scientific consensus. Harmful Algae 8 3-13.

HENDERSON R, PARSONS SA and JEFFERSON B (2008) The impact of algal properties and pre-oxidation on solid-liquid separation of algae. Water Res. 42 (8-9) 1827-1845.

HO L and NEWCOMBE G (2010) Optimising water treatment processes for the removal of cyanobacteria and their metabolites. $2^{\text {nd }}$ National Cyanobacterial Workshop, 2-3 August 2010, Melbourne. SA Water, Melbourne.

HOEGER SJ, HITZFELD BC and DIETRICH R (2005) Occurrence and elimination of cyanobacterial toxins in drinking water treatment plants. Toxicol. Appl. Pharmacol. 203 231-242.

JANSE VAN VUUREN S, TAYLOR J, GERBER A and VAN GINKEL C (2006) Easy identification of the most common freshwater algae. A guide for the identification of microscopic algae in South Africa. North-West University and Department of Water Affairs and Forestry. ISBN: 0-621-35471-6. 200 pp.

KHAN S, AFFAN A, HAQUE M, IMOKAWA M and UENO Y (2001) Determination of microcystins in natural and drinking water of Bangladesh by ELISA. Proc. Fifth International Conference on Toxic Cyanobacteria, 15-20 July 2001, Noosa, Australia.

LI Y, CAO W, SU C and HONG H (2011) Nutrient sources and composition of recent algal blooms and eutrophication in the northern Jiulong River, Southeast China. Mar. Pollut. Bull. 63 (5-12) 249-254.

LUND JWG, KIPLING C and LE CREN ED (1958) The inverted microscope method of estimating algal numbers and the statistical basis of estimations by counting. Hydrobiologia 11 143-170.

MA J and LIU W (2002) Effectiveness of mechanism of potassium ferrate (VI) preoxidation for algae removal by coagulation. Water Res. 36 871-878.

MEREL S, CLÉMENT M and THOMAS O (2010) State of the art on cyanotoxins in water and their behaviour towards chlorine. Toxicon 55 (4) 677-691.

NEWCOMBE G (2009) International guidance manual for management of toxic cyanobacteria. Global Water Research Coalition. Water Quality Research, Adelaide. ISBN: 978-90-77622-21-6.

PALMER CM (1980) Algae and Water Pollution - The Identification, Significance, and Control of Algae in Water Supplies and in Polluted Water. Castle House Publications Ltd., Tunbridge Wells.

RAND WATER (2001) Rand Water treatment philosophy and guide. Water Treatment and Technology Division, Rand Water, Johannesburg. 100 pp.

REYNOLDS CS (1984) The Ecology of Freshwater Phytoplankton. Cambridge University Press, Cambridge.

RODRÍGUEZ E, SORDO A, METCALF JS and ACERO JL (2007) Kinetics of the oxidation of cylindrospermopsin and anatoxin-a with chlorine, monochloramine and permanganate. Water Res. 41 2048-2056.

ROSITANO J, NEWCOMBE G, NICOLSON B and SZTAJNBOK P (2001) Ozonation of NOM and algal toxins in four treated waters. Water Res. 35 23-32.

SITHOLE SP, NXUMALO EN, MHLANGA SD, SALIPIRA KL, MAMBA BB, KRAUSE RM and MALEFETSE TJ (2007) Application of cyclodextrin polymers in the removal of organic pollutants from water. WRC Report No. KV 194/07. Water Research Commission, Pretoria.

SWANEPOEL A and DU PREEZ H (2010) Chlorophyll breakthrough into the potable water at Vereeniging. Analytical Services Memorandum, Rand Water. Rand Water, Johannesburg.

SWANEPOEL A, DU PREEZ H, SCHOEMAN C, JANSE VAN VUUREN S and SUNDRUM A (2008 b) Condensed laboratory methods for monitoring phytoplankton, including cyanobacteria, in South African freshwaters. WRC Report No. TT 323/08. Water Research Commission, Pretoria.

SWANEPOEL A, DU PREEZH H, DUSRATH I and RAJELE M (2008a) Ceratium hirundinella reveals algal penetration into the potable water at Rand Water. Proc. Water Institute of Southern Africa (WISA 2008), 18-22 May 2008, Sun City, South Africa.

TER BRAAK CJF (1996) Unimodal models to relate species to environment. DLO-Agricultural Mathematics Group, Wageningen. 266 pp.

VAN DER WALT M, KRÜGER M and VAN DER WALT C (2009) The South African oxidation and disinfection manual. WRC Report No. TT 406/09. Water Research Commission, Pretoria.

VAN DER WALT N (2010) Investigation into the occurrence of the dinoflagellate, Ceratium hirundinella, in source water and the impact thereof on drinking water purification. Report number: CER.07.2010.2. Scientific Services, Rand Water, Johannesburg. 177 pp.

VAN GINKEL CE and CONRADIE B (2001) Potential toxic algal incident in the Orange River, Northern Cape, 2000. Report number: N/D801/12/EEQ/0800, Institute for Water Quality Studies, Department of Water Affairs and Forestry, Pretoria.

VAN GINKEL CE, HOLS BC and VERMAAK E (2001) A Ceratium hirundinella bloom in Hartbeespoort Dam, South Africa. Water SA 27(2) 269-276.

VAULAT D (2001) Phytoplankton. Centre Nationale de la Recherche Scientifique et Université Pierre et Marie Curie, Roscoff, France.

VENTER A, JANSE VAN VUUREN and PIETERSE AJH (2003) Oscillatoria simplicissma: An autecological study. Water SA 29 (1)101-104.

WESTERHOFF P, SUMMERS RS, CHOWDHURY Z and KOMMINENI S (2005) Ozone-enhanced biofiltration for geosmin and MIB removal. AWWA Research Foundation, Denver. 1-220.

ZAMYADI A, HO L, NEWCOMBE G and BUSTAMANTE H (2011) Fate of toxic cyanobacterial cells and disinfection by-products formation after chlorination. Water Res. 46 (5) 1524-1535.

ZAMYADI A, HO L, NEWCOMBE G, BUSTAMANTE $\mathrm{H}$ and PRÉVOST M (2012a) Fate of toxic cyanobacterial cells and 
disinfection by-products after chlorination. Water Res. 46 (5) 1524-1534.

ZAMYADI A, MACLEOD SL, FAN Y, MCQUAID N, DORNER

S, SAUVÉ S and PRÉVOST M (2012b) Toxic cyanobacterial breakthrough and accumulation in a drinking water plant. A monitoring and treatment challenge. Water Res. 46 1511-1523.

\section{APPENDIX}

\section{Table A1}

ANOVA results indicating statistically significant differences (or lack thereof) between 4 sets of data obtained from the source water (SW), after sedimentation (AS), after filtration (AF) and in the final water (FW). Average results are indicated below and the level of significance for statistical analysis was set at $p=0.05$. $(\checkmark)$ Statistically significant difference; (X) Not enough evidence to suggest any statistically significant difference.

\begin{tabular}{|c|c|c|c|c|c|c|c|}
\hline \multirow[t]{2}{*}{ Phytoplankton } & & \multicolumn{4}{|c|}{ Sampling localities } & \multicolumn{2}{|c|}{$p$-value } \\
\hline & & SW & AS & $\mathrm{AF}$ & FW & & \\
\hline Cyanophyceae & (cells/ml) & 399 & 149 & 34 & 14 & $2 \times 10^{-23}$ & $\checkmark$ \\
\hline Dinophyceae & (cells/ml) & 4 & 4 & 1 & 2 & $2.6 \times 10^{-03}$ & $\checkmark$ \\
\hline Total phytoplankton concentration & (cells/ml) & 771 & 203 & 51 & 25 & $4.02 \times 10^{-38}$ & $\checkmark$ \\
\hline
\end{tabular}

\begin{tabular}{|c|c|c|}
\hline \multicolumn{3}{|c|}{$\begin{array}{c}\text { Table A2 } \\
\text { T-test output to evaluate statistically significant differences } \\
\text { between Anabaena data obtained at different sampling } \\
\text { localities after the performance of conventional water } \\
\text { treatment processes; } p=0.05\end{array}$} \\
\hline & $\begin{array}{l}\text { Source } \\
\text { water }\end{array}$ & $\begin{array}{c}\text { After } \\
\text { sedimentation }\end{array}$ \\
\hline Mean (cells/ml) & 751 & 195 \\
\hline Variance & 2154891.98 & 378288.97 \\
\hline t statistic & 3.37 & \\
\hline $\mathrm{P}(\mathrm{T}<=\mathrm{t})$ two-tail( $\mathrm{p}$-value $)$ & $9.1 \times 10^{-4}$ & \\
\hline \multirow[t]{2}{*}{ t Critical two-tail } & 1.97 & \\
\hline & $\begin{array}{c}\text { After } \\
\text { sedimentation }\end{array}$ & $\begin{array}{c}\text { After } \\
\text { filtration }\end{array}$ \\
\hline Mean (cells/m $\ell$ ) & 195 & 25 \\
\hline Variance & 378288.97 & 3559.17 \\
\hline t statistic & 2.65 & \\
\hline $\mathrm{P}(\mathrm{T}<=\mathrm{t})$ two-tail & $8.8 \times 10^{-3}$ & \\
\hline \multirow[t]{2}{*}{ t Critical two-tail } & 1.97 & \\
\hline & After filtration & Final water \\
\hline Mean (cells/m $/$ ) & 25 & 16 \\
\hline Variance & 3559.17 & 706.71 \\
\hline t statistic & 1.38 & \\
\hline $\mathrm{P}(\mathrm{T}<=\mathrm{t})$ two-tail & $8.4 \times 10^{-2}$ & \\
\hline t Critical two-tail & 1.97 & \\
\hline
\end{tabular}

\begin{tabular}{|c|c|c|}
\hline \multicolumn{3}{|c|}{$\begin{array}{c}\text { Table A3 } \\
\text { T-test output to evaluate statistically significant differences } \\
\text { between Microcystis_data obtained at different sampling } \\
\text { localities after the performance of conventional water } \\
\text { treatment processes; } p=0.05\end{array}$} \\
\hline & $\begin{array}{c}\text { Source } \\
\text { water }\end{array}$ & $\begin{array}{c}\text { After } \\
\text { sedimentation }\end{array}$ \\
\hline Mean (cells/ml) & 289 & 53 \\
\hline Variance & 508733.41 & 21801.05 \\
\hline t statistic & 3.11 & \\
\hline $\mathrm{P}(\mathrm{T}<=\mathrm{t})$ two-tail( $\mathrm{p}$-value $)$ & $2.1 \times 10^{-3}$ & \\
\hline \multirow[t]{2}{*}{ t Critical two-tail } & 1.97 & \\
\hline & $\begin{array}{c}\text { After } \\
\text { sedimentation }\end{array}$ & After filtration \\
\hline Mean (cells/ml) & 53 & 7 \\
\hline Variance & 21801.05 & 467.69 \\
\hline t statistic & 2.94 & \\
\hline $\mathrm{P}(\mathrm{T}<=\mathrm{t})$ two-tail & $3.7 \times 10^{-3}$ & \\
\hline \multirow[t]{2}{*}{ t Critical two-tail } & 1.97 & \\
\hline & After filtration & Final water \\
\hline Mean (cells/ml) & 7 & 2 \\
\hline Variance & 467.69 & 42.98 \\
\hline t statistic & 2.01 & \\
\hline $\mathrm{P}(\mathrm{T}<=\mathrm{t})$ two-tail & $4.5 \times 10^{-2}$ & \\
\hline t Critical two-tail & 1.97 & \\
\hline
\end{tabular}


Table A4

T-test output to evaluate statistically significant differences between Ceratium data obtained at different sampling localities after the performance of conventional water treatment processes; $p=0.05$

\begin{tabular}{|c|c|c|}
\hline & $\begin{array}{c}\begin{array}{c}\text { Source } \\
\text { water }\end{array} \\
\end{array}$ & $\begin{array}{c}\text { After } \\
\text { sedimentation }\end{array}$ \\
\hline Mean (cells/m $\ell$ ) & 9 & 5 \\
\hline Variance & 1058.10 & 202.26 \\
\hline t statistic & 1.10 & \\
\hline $\mathrm{P}(\mathrm{T}<=\mathrm{t})$ two-tail $(\mathrm{p}$-value $)$ & $2.7 \times 10^{-1}$ & \\
\hline \multirow[t]{2}{*}{ t Critical two-tail } & 1.97 & \\
\hline & $\begin{array}{c}\text { After } \\
\text { sedimentation }\end{array}$ & $\begin{array}{c}\text { After } \\
\text { filtration }\end{array}$ \\
\hline Mean $($ cells $/ \mathrm{m} \ell)$ & 5 & 1 \\
\hline Variance & 202.26 & 18.39 \\
\hline t statistic & 2.55 & \\
\hline $\mathrm{P}(\mathrm{T}<=\mathrm{t})$ two-tail & $1.1 \times 10^{-2}$ & \\
\hline \multirow[t]{2}{*}{ t Critical two-tail } & 1.97 & \\
\hline & After filtration & Final water \\
\hline Mean (cells $/ \mathrm{m} \ell)$ & 1 & 2 \\
\hline Variance & 18.39 & 68.63 \\
\hline t statistic & -0.90 & \\
\hline $\mathrm{P}(\mathrm{T}<=\mathrm{t})$ two-tail & $3.6 \times 10^{-1}$ & \\
\hline t Critical two-tail & 1.97 & \\
\hline
\end{tabular}

\section{Table A5}

T-test output to evaluate statistically significant differences between geosmin data obtained at different sampling localities after the performance of conventional water treatment processes; $p=0.05$

\begin{tabular}{|c|c|c|}
\hline \multicolumn{3}{|c|}{$\begin{array}{c}\text { Table A5 } \\
\text { T-test output to evaluate statistically significant differences } \\
\text { between geosmin data obtained at different sampling } \\
\text { localities after the performance of conventional water } \\
\text { treatment processes; } p=0.05\end{array}$} \\
\hline & $\begin{array}{l}\text { Source } \\
\text { water }\end{array}$ & $\begin{array}{c}\text { After } \\
\text { sedimentation }\end{array}$ \\
\hline Mean (ng/l) & 8.95 & 6.21 \\
\hline Variance & 139.02 & 58.52 \\
\hline t statistic & 1.89 & \\
\hline $\mathrm{P}(\mathrm{T}<=\mathrm{t})$ two-tail $(\mathrm{p}$-value $)$ & $6.1 \times 10^{-2}$ & \\
\hline \multirow[t]{2}{*}{ t Critical two-tail } & 1.97 & \\
\hline & $\begin{array}{c}\text { After } \\
\text { sedimentation }\end{array}$ & $\begin{array}{c}\text { After } \\
\text { filtration }\end{array}$ \\
\hline Mean (ng/l) & 6.21 & 4.56 \\
\hline Variance & 58.52 & 34.49 \\
\hline t statistic & 1.65 & \\
\hline $\mathrm{P}(\mathrm{T}<=\mathrm{t})$ two-tail & $1.0 \times 10^{-1}$ & \\
\hline \multirow[t]{2}{*}{ t Critical two-tail } & 1.97 & \\
\hline & After filtration & Final water \\
\hline Mean (ng/l) & 4.56 & 4.27 \\
\hline Variance & 34.49 & 12.47 \\
\hline t statistic & 0.39 & \\
\hline $\mathrm{P}(\mathrm{T}<=\mathrm{t})$ two-tail & $6.9 \times 10^{-1}$ & \\
\hline t Critical two-tail & 1.97 & \\
\hline
\end{tabular}

\section{Table A6}

T-test output to evaluate statistically significant differences between TPP data obtained at different sampling localities after the performance of conventional water treatment processes; $p=0.05$

\begin{tabular}{|l|c|c|}
\hline & $\begin{array}{c}\text { Source } \\
\text { water }\end{array}$ & $\begin{array}{c}\text { After } \\
\text { sedimentation }\end{array}$ \\
\hline Mean $(\mu \mathrm{g} / \mathrm{\ell})$ & 6.95 & 1.70 \\
\hline Variance & 17.25 & 12.86 \\
\hline $\mathrm{t}$ statistic & 9.24 & \\
\hline $\mathrm{P}(\mathrm{T}<=\mathrm{t})$ two-tail( $\mathrm{p}$-value) & $6.2 \times 10^{-17}$ & \\
\hline $\mathrm{t}$ Critical two-tail & 1.97 & \\
\hline & $\begin{array}{c}\text { After } \\
\text { sedimentation }\end{array}$ & $\begin{array}{c}\text { After } \\
\text { filtration }\end{array}$ \\
\hline Mean $(\mu \mathrm{g} / \mathrm{\ell})$ & 1.70 & 0.65 \\
\hline Variance & 12.86 & 0.44 \\
\hline $\mathrm{t}$ statistic & 2.76 & \\
\hline $\mathrm{P}(\mathrm{T}<=\mathrm{t}) \mathrm{two}-\mathrm{tail}$ & $6.3 \times 10^{-3}$ & \\
\hline $\mathrm{t}$ Critical two-tail & 1.97 & \\
\hline & After filtration & Final water \\
\hline Mean $(\mu \mathrm{g} / \mathrm{\ell})$ & 0.65 & 0.13 \\
\hline Variance & 0.44 & 0.04 \\
\hline $\mathrm{t}$ statistic & 7.34 & \\
\hline $\mathrm{P}(\mathrm{T}<=\mathrm{t}) \mathrm{two}$-tail & $6.5 \times 10^{-12}$ & \\
\hline $\mathrm{t}$ Critical two-tail & 1.97 & \\
\hline
\end{tabular}


http://dx.doi.org/10.4314/wsa.v39i5.19 Available on website http://www.wrc.org.za

ISSN 0378-4738 (Print) $=$ Water SA Vol. 39 No. 5 October 2013 ISSN 1816-7950 (On-line) = Water SA Vol. 39 No. 5 October 2013 